\section{Commentary: Vasoplegia after aortic surgery: Looking for options}

\author{
Derek Serna-Gallegos, MD, ${ }^{\mathrm{a}, \mathrm{b}}$ and \\ Ibrahim Sultan, MD ${ }^{\mathrm{a}, \mathrm{b}}$
}

Vasoplegic shock after cardiac surgery can be a challenging clinical problem to manage and can affect every aspect of cardiac surgery, including coronary and valve surgery, aortic surgery, ventricular assist devices, and heart transplantation. ${ }^{1,2}$ While vasoplegia in cardiac surgery is typically directly related to the use of cardiopulmonary bypass, this has been seen in off-pump surgery as well. For this reason, it is our practice to routinely pause the use of angiotensinconverting enzyme inhibitors and angiotensin receptor blockers 5 days before cardiac surgery when it is safe to do so.

The initial management for vasoplegic shock includes ruling out any other causes of refractory hypotension, including sepsis, bleeding, metabolic and/or electrolyte derangements, hypoxia, or cardiac failure. In thoracic aortic surgery, as in this case, the consequences of hypotension can be especially detrimental and permanent if they result in spinal cord ischemia. ${ }^{3}$ After a diagnosis of vasoplegia is made, the toolbox with which to address the highoutput, low vascular resistance cardiovascular collapse must be evaluated and vasopressors and intravenous volume expansion become the first line in the tools of the trade. The algorithm presented by the authors in this case report summarizes the stepwise progression of vasopressor use. Over the years, several new tools have been added to the toolbox with which to address the difficult problem of vasoplegia. Several pharmacologic agents that have been demonstrated as being effective in vasoplegia include terlipressin, methylene blue, hydroxocobalamin, angiotensin II (Giapreza),

From the a Division of Cardiac Surgery, Department of Cardiothoracic Surgery, University of Pittsburgh, Pittsburgh, Pa; and ${ }^{\mathrm{b} H e a r t}$ and Vascular Institute, University of Pittsburgh Medical Center, Pittsburgh, Pa.

Disclosures: The authors reported no conflicts of interest.

The Journal policy requires editors and reviewers to disclose conflicts of interest and to decline handling or reviewing manuscripts for which they may have a conflict of interest. The editors and reviewers of this article have no conflicts of interest.

Received for publication Aug 23, 2020; revisions received Aug 23, 2020; accepted for publication Aug 26, 2020; available ahead of print Sept 14, 2020.

Address for reprints: Ibrahim Sultan, MD, Division of Cardiac Surgery, Department of Cardiothoracic Surgery, University of Pittsburgh, Center for Thoracic Aortic Disease, Heart and Vascular Institute, University of Pittsburgh Medical Center, 5200 Centre Ave, Suite 715, Pittsburgh, PA 15232 (E-mail: sultani@upmc.edu). JTCVS Techniques 2020;4:76

2666-2507

Copyright $@ 2020$ The Authors. Published by Elsevier Inc. on behalf of The American Association for Thoracic Surgery. This is an open access article under the CC BY-NCND license (http://creativecommons.org/licenses/by-nc-nd/4.0/).

https://doi.org/10.1016/j.xjtc.2020.08.071

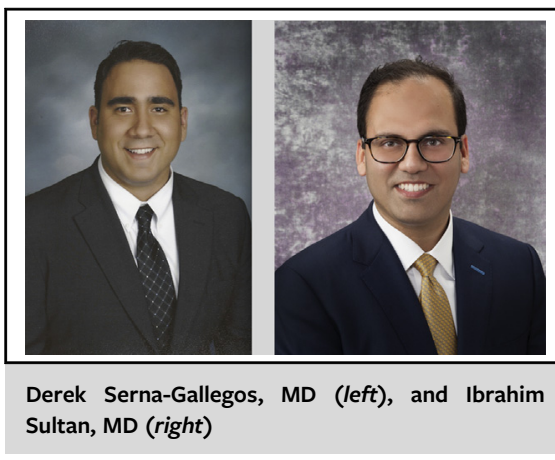

CENTRAL MESSAGE

Angiotensin II can be successfully used as part of multimodality therapy for the treatment of vasoplegia in patients who undergo partial cardiopulmonary bypass.

vitamin $\mathrm{C}$, flurbiprofen (Ropion), and hydrocortisone. ${ }^{4}$ As is evident by the plethora of options, no one option has proven to be the obvious superior agent. Within the circumstances of vasoplegia, by definition, the patients are rather unstable and we as clinicians try to use the "kitchen-sink" approach in this scenario to help alter the patient's clinical course. In this issue of the Journal, Chatterjee and colleagues ${ }^{5}$ report their experience in a patient undergoing thoracoabdominal aortic aneurysm repair and their successful use of angiotensin II in this setting. The authors have one of the largest experiences with open thoracoabdominal aneurysm repair, and their efforts to optimize perioperative management in this critically ill cohort are to be commended.

\section{References}

1. de Waal EEC, van Zaane B, van der Schoot MM, Huisman A, Ramjankhan F, van Klei WA, et al. Vasoplegia after implantation of a continuous flow left ventricular assist device: incidence, outcomes and predictors. BMC Anesthesiol. 2018;18:185.

2. Kortekaas KA, Lindeman JH, Reinders ME, Palmen M, Klautz RJ, de Groot PG, et al. Pre-existing endothelial cell activation predicts vasoplegia after mitral valve surgery. Interact Cardiovasc Thorac Surg. 2013;17:523-30.

3. Sultan I, Dufendach K, Cardounel A, Navid F, Gleason TG. Intercostal artery reimplantation with saphenous vein during thoracoabdominal aortic replacement. $J$ Thorac Cardiovasc Surg. 2018;155:1963-5.

4. Busse LW, Barker N, Petersen C. Vasoplegic syndrome following cardiothoracic surgery-review of pathophysiology and update of treatment options. Crit Care. 2020;24:36.

5. Chatterjee S, Preventza O, Mousavi M, Orozco-Sevilla V, LeMaire SA, Coselli JS. Successful use of angiotensin II for vasoplegia after thoracoabdominal aortic aneurysm repair. J Thorac Cardiovasc Surg Tech. 2020;4:72-5. 